\title{
Electron Beam Therapy
}

National Cancer Institute

\section{Source}

National Cancer Institute. Electron Beam Therapy. NCI Thesaurus. Code C15650.

Radiation therapy using electron beam. 